\title{
THREE EXECUTIONS
}

Death in a guillotine is never painful but it is confusing. The basket, the ideal reservoir is never used twice so long before that sharp moment both the basket and its future head may actually be in the same room. The condemned should know this so he may at least weave his own crater. Death in a guillotine is an effortless feeding, the promise of an incision, love.

Crossbows haven't been popular lately

but like those cautious women who embrace shadows who have as a final wish only their dream of an innocently thin mouth, they're lifted over the shoulders for protection. This death goes in narrow and spreads.

This death is a feather's whistle, the spine's brother.

Mayakovsky's social command is the remaining ash from the last execution I allowed, so I know there is only one song and only one day for the deaf to sing but why was my womb so cold and why is my map of your voodoo camp stuffed in that wet syringe? There's so much I'll never know, like how exactly my executioner loves me or who actually owns the missing half of my body. But is this a final moment? Then I'm so grateful for these blue volts this death a pure excess. 